\title{
M. ZEN GOMO DALAM GERAKAN ANTI KORUPSI PADA DEKADE I REFORMASI DI SUMATERA BARAT
}

\author{
Rizki Ilahi ${ }^{1,(*)}$, Mestika Zed ${ }^{1}$, Erniwati ${ }^{1}$ \\ 1Jurusan Sejarah Fakultas Ilmu Sosial Universitas Negeri Padang \\ ${ }^{(*)}$ riski
}

\section{ABSTRACT}

This is a study thematic biographer who discusses about M. Zen Gomo during join in the world of politics. The focused study is described and analyze the act of he did in motion anti-corruption in the reform. The purpose of this research gives descriptions of political activity M. Zen Gomo and place in movement anti-corruption in West Sumatra. The results of the study are that $M$. Zen Gomo joins politics since the end of the new order and the establishment of a national mandate party. While in politics and was a member of the council, he often faced with various problems that have contrary to principle to his refusal. Ranging from refuse to accept money in a local election in 2000. Refused money "unexpected" from the executive. The top of their actions is demanded that Sumbar 2002 budget to revised by his associates. The act of he did is also be supported by people who joined in Forum Peduli Sumatera Barat (FPSB), So that in 2004, some 43 council members $W$ est Sumatra suspect in the corruption case.

Keywords: Biography, Reform, Anti-Corruption Movement

\section{PENDAHULUAN}

"Sepertinya kebohongan itu begitu dahsyat terjadi, sehingga memaksa anggota DPRD Sumbar, M. Zen Gomo harus buka kartu pada acara dengar pendapat dengan Universitas Negeri Padang (UNP) Sabtu lalu (6/4)." (Redaksi, 2002a). Inilah sedikit potongan berita di Harian Singgalang, yang menjadi penanda otokritik yang ia lakukan telah terdengar sampai ke masyarakat luas.

M. Zen Gomo merupakan politisi dari Sumatera Barat. Ia mulai bergabung di dunia politik setelah berakhirnya Orde Baru, tepatnya setelah Partai Amanat Nasional dideklarasikan. Melalui partai yang lahir dari 
semangat reformasi inilah, Zen memulai karirnya di dunia politik. Pada saat menjabat sebagai anggota DPRD Sumatera Barat, ia melakukan otokritik, dengan meminta agar APBD Sumbar tahun 2002 direvisi, karena bertentangan dengan peraturan yang ada, hingga akhirnya memilih berhenti dari DPRD. Kasus ini merupakan satu-satunya yang terjadi di Indonesia (Isra, 2010).

Kasus otokritik yang dilakukan M. Zen Gomo terhadap DPRD Sumatera Barat, tentunya tidak bisa dilepaskan dari jiwa zamannya, yaitu Reformasi 1998. Reformasi yang ditandai dengan tubangnya rezim orde baru yang bersifat diktator, dan sehingga pada saat yang sama Indonesia juga mengalami masa transisi ke demokrasi (demokratisasi) (International IDEA, 2000). Selain itu juga dikuatkan dengan keluarkannya Ketetapan MPR No. XI/MPR/ 1998 tentang penyelenggaraan negara yang bersih bebas Korupsi, Kolusi dan Nepotisme (KKN). Sederhananya, reformasi di Indonesia pada tahun 1998 juga memberikan pengaruh terhadap demokratisasi di Indonesia serta upaya untuk membersihkan pemerintahan dari praktik korupsi.

Penelitian ini mengkaji tentang biografi tematis M. Zen Gomo. Tokoh politik yang baru bergabung di dunia politik setelah berakhirnya rezim Orde Baru. Namun, cukup memainkan peran yang signifikan, terutama pada awal masa reformasi di Sumatera Barat. Hal ini disebabkan karena upaya yang ia lakukan dalam mewujudkan salah satu cita-cita reformasi, yaitu semangat anti-Korupsi Kolusi Nepotisme (KKN). ${ }^{1}$

Pentingnya penelitian ini untuk dilakukan ialah karena pada masa itu, di tengah semangat reformasi yang menjadi arah baru Indonesia, dalam saat yang sama juga terjadi distorsi nilai di tengah masyarakat. Sehingga dengan berlakunya otonomi daerah, banyak muncul kasus-kasus korupsi di daerahdaerah yang dilakukan oleh penguasa dengan memanfaatkan hukum dan kekuasaan yang ada. Tindakan M. Zen Gomo muncul sebagai sikap yang berbeda dari kasus tersebut. Artikel ini berusaha untuk menjawab tentang kegiatan politik M. Zen Gomo selama bergabung di dunia politik dan analisis posisi M. Zen Gomo dalam gerakan anti korupsi di Sumatera Barat.

${ }^{1}$ Terdapat enam tuntutan mahasiswa yang menjadi tujuan reformasi dengan agenda yaitu (1) turunkan dan adili Soeharto, (2) Otonomi daerah seluas-luasnya, (3) cabut Dwi Fungsi ABRI, (4) tolak Korupsi, Kolusi dan Nepotisme (KKN) (5) penegakkan supremasi hukum (6) pengusutan pelanggaran HAM. 


\section{METODE}

Biografi adalah sebuah "genre" khusus dari studi sejarah. Studi biografi juga mengikuti alur atau tahapan metode penelitian sejarah secara umum, yaitu (1) Tahapan heuristik, yaitu kegiatan mencari atau mengumpulkan sumber, informasi dan jejak masa lalu. (2) Tahapan kritik sumber, (3) Tahapan interpretasi dan terakhir (4) tahapan historiografi (penulisan) (Gottschalk, 1975).

Langkah kerja dalam metode biografi yang digunakan dalam penelitian ini, yaitu pertama, menulis tentang subjek yang akan diteliti dan mengemukakan pentingnya M. Zen Gomo tersebut untuk diteliti. Kedua, mulai menggali lebih dekat serangkaian pengalaman objektif dari kehidupan tokoh yang akan diteliti. Ketiga, mencari dan menggali data-data yang relevan dengan tokoh atau zamannya, baik dengan wawancara langsung bersama tokoh (jika masih hidup) atau melalui informan yang kenal dekat dengannya, serta data-data yang diperoleh dari sumber arsip/dokumen. Keempat, menganalisis data yang telah diperoleh dan mengidentifikasi peristiwa dn pengalaman-pengalaman penting, unik serta khas dari tokoh. Analisis data tersebut dapat dilakukan dalam langkah-langkah sebagai berikut; a) Membuat dan mengatur data yang telah dikumpulkan berdasarkan "heading" atau tema-tema terkait dengan kehidupan tokoh; b) Menggali pernyataan faktual dari sumber yang tersedia, termasuk interpretasi atau penilaian murni dari sudut pandang tokoh; c) Mendeskripsikan kronologi fakta-fakta tentang kehidupan tokoh sejalan dengan "siklus kehidupan" yang ia lewati; d) Mengidentifikasi dan mendeskripsikan kisah hidup serta menentukan "titik balik" si tokoh; e) Menyusun analisis secara sistematis. Kelima, melakukan eksplorasi makna dari data yang sudah diperoleh serta mencari keterangan, kejelasan dan arti lain yang mendekati. Keenam, tahap akhir, peneliti mengaitkan arti yang diperoleh kepada struktur yang lebih besar guna menjelaskan arti yang diperoleh pada tahap sebelumnya (Denzim \& Lincoln, 1994).

\section{HASIL DAN PEMBAHASAN}

Mohammad Zen Gomo (selanjutnya ditulis M. Zen Gomo) lahir di Rambatan, Tanah Datar pada tanggal 25 April 1943. Ayahnya bernama Jamil dan Ibunya Rabiah. Ia merupakan anak bungsu dari empat bersaudara. Tumbuh dalam lingkungan keluarga yang taat beragama serta kuat dengan pengaruh Muhammadiyah dan Masyumi, membuat Zen kecil dekat dengan aktivitas politik Islam. Lingkungan masa kecil ini juga 
membentuknya untuk tumbuh menjadi seseorang yang memegang kuat moralitas kejujuran dala hidupnya.

Setelah pensiun dari dunia perbankan, M. Zen Gomo memutuskan untuk kembali ke Padang. ${ }^{2}$ Di Kota Padang, ia mendapat tawaran bekerja sebagai dosen di AMIK Jaya Nusa. Dalam perkembangannya ia juga dipercaya menjadi direktur di akademi itu. Bekerja sebagai dosen dan menetap di Padang, Pada masa ini, ia juga aktif dalam beberapa organisasi, seperti di Muhammadiyah Sumatera Barat sebagai anggota manjelis ekonomi, pengurus ICMI Sumbar, dan menjadi perintis berdirinya Baitul Maal wat Tamwil Taqwa (BMT) Muhammadiyah Sumbar. Aktif dalam kepengurusan Muhammadiyah ini juga membawanya untuk ikut aktif dalam kegitan politik Sumatera Barat pada masa reformasi.

Setelah Indonesia memasuki zaman reformasi yang berdampak pada proses demokratisasi, muncul berbagai partai politik baru. Salah satunya ialah Partai Amanat Nasional (PAN). Sehari setelah partai tersebut dideklarasikan di Jakarta, maka di Padang juga diadakan rapat untuk membentuk Komite Pembentuk Pimpinan Wilayah (KPPW) PAN Sumatera Barat yang diinisiatori oleh Dasman Lanin. Setelah partai tersebut dideklarasikan di Sumatera Barat, pada tanggal 11 Oktober 1998 dilaksanakan Musyawarah Wilayah (Musywil) I PAN Sumatera Barat yang menghasilkan pembentukan tim formatur penyusunan personalia DPW PAN Sumatera Barat periode 1998-1999 dengan ketuanya Arwan Kasri. Pada saat itu M. Zen Gomo ditunjuk sebagai anggota Dewan Ekonomi PAN Sumbar (DPW PAN Sumatera Barat, n.d.), selanjutnya pada tahun 2000 ia diangkat menjadi ketua di bidang yang sama (Gomo, n.d.-a).

Menjelang pemilu 1999, PAN Sumatera Barat juga menyiapkan kadernya untuk menjadi calon anggota legislatif, baik tingkat Pusat, Provinsi maupun Kabupaten/Kota. Di Tanah Datar, M. Zen Gomo dan beberapa orang kader DPD PAN mengadakan rapat untuk penentuan kader yang akan menjadi calon anggota legislatif (DPRD) tingkat II (Kabupaten/Kota) dan Tingkat I (Provinsi). Pada waktu itu M. Zen Gomo diusulkan sebagai calon anggota legislatif tingkat I. Pada saat melakukan kampanye di Tanah Datar, partai PAN mendapat sambutan yang hangat

${ }^{2}$ Ia bekerja di Bank BRI sejak tahun 1965, pernah menduduki beberapa jabatan yang cukup penting untuk tingkat cabang di antaranya menjadi Kepala Bagian Kantor Pemasaran Wilayah (Kabag Kapewil) BRI Pekanbaru tahun 1978, Wakil Kepala Kantor Cabang (Wa-Kakanca) BRI Padang tahun 1983, Begitu pula pada tahun 1987, menjadi Wakil Pimpinan Cabang (Wapimca) BRI Padang, pimpinan Cabang BRI di Sibolga, namun empat tahun setelah itu ia dipindahkan sebagai Kabag Pemerikasaan Kanis BRI Banda Aceh. Saat bekerja di Aceh, M. Zen Gomo memeutuskan untuk mundur dari pekerjaannya. 
dari masyarakat. Selain tingginya antusias dalam menghadiri kampanye, masyarakat juga memberikan sumbangan sukarela untuk membiayai kegiatan kampanye tersebut.

Pada tanggal 7 Juni 1999 pemilu pertama di zaman reformasi dilaksanakan yang diikuti oleh 48 partai politik. Berdasarkan perolehan suara pada pemilu 1999 di Sumatera Barat, maka hanya ada 12 partai politik yang memenuhi syarat untuk menempatkan wakilnya di DPRD provinsi. Golkar tampil sebagai pemenang di Sumatera Barat dan memperoleh 12 kursi, sementara PAN berada di posisi kedua mendapatkan 11 kursi di DPRD Sumatera Barat. Salah seorang dari 11 itu ialah M. Zen Gomo (Asnan, 2006).

Satu bulan setelah itu, sebanyak 52 orang Anggota DPRD Sumatera Barat yang terpilih dilantik dalam sidang istimewa anggota DPRD oleh Ketua Pengadilan Tinggi Sumatera Barat atas nama Ketua Mahakamah Agung (Menteri Dalam Negeri, 1999). Selanjutnya pada 21 September 1999 juga dilakukan pelantikan dan pengambilan sumpah susulan terhadap tiga orang anggota dewan lainnya (DPRD Sumatera Barat, 2004). M. Zen Gomo merupakan salah satu dari 55 orang anggota DPRD Sumatera Barat yang dilantik.

Dalam rapat paripurna tanggal 22 September 1999, dilaksanakan pemilihan Pimpinan DPRD Provinsi Sumatera Barat dengan 1 orang ketua dan 3 orang wakil ketua, yang dimenangkan oleh Arwan Kasri dari Fraksi PAN sebagai Ketua. Pada tanggal 12 Oktober 1999 dilaksanakan musyawarah tentang penetapan komisi-komisi, Panitia Musyawarah dan Panitia Anggaran DPRD Sumatera Barat. M. Zen Gomo terpilih sebagai Ketua Komisi C yang membidangi masalah keuangan, perbankan dan perusahaan daerah. Di samping itu, ia juga terpilih sebagai anggota panitia anggaran DPRD Sumatera Barat.

Enam bulan pertama, kinerja dan kebijakan DPRD Sumatera Barat berjalan sesuai dengan harapan rakyat. Kegiatan pertama DPRD Sumatera Barat yang sejalan dengan aspirasi rakyat ialah mengirimkan petisi kepada Meneteri Negara Pendayagunaan BUMN agar PT Semen Padang keluar dari PT Semen Gresik. Petisi tersebut ditetapkan dalam suatu keputusan Anggota DPRD Provinsi Sumatera Barat Nomor: 10/SB/1999 pada tanggal 3 September 1999. Petisi ini keluar hanya berjarak seminggu setelah DPRD Sumatera Barat dilantik dan diambil sumpah jabatannya (DPRD Sumatera Barat, 2004).

Dalam perkembangannya kinerja dan kebijakan DPRD mulai mendapat kritik dari rakyat. Seperti pemilihan gubernur tahun 2000 yang berlangsung dalam Sidang Paripurna DPRD Sumatera Barat tersebut 
mendapat sorotan dari masyarakat dan media masa. Masalah itu terkait dengan isu politik uang. Bahkan ada bocoran bahwa pencoblosan dalam surat suara tersebut terdapat kode-kode sebagai bentuk transaksi politik uang yang dilakukan oleh salah satu pasang calon (Lanin, 2016; Ruzuar, 2016). ${ }^{3}$ Ketika proses penyaringan ini, M. Zen Gomo pernah didatangi oleh salah satu tim sukses calon untuk meloloskan pasangannya, namun ia menolak dan menjawab "saya patuh kepada keputusan partai yang telah menetapkan calonnya” (Gomo, n.d.-b).

Begitupun pada masa reses, DPRD Sumatera Barat melaksanakan studi banding ke luar daerah. Tindakan tersebut juga mendapat kritik dari masyarakat, karena menghabiskan dana sekitar Rp200 juta dalam setiap kali perjalanan. Bahkan dalam studi banding tersebut beredar berita bahwa dalam setiap kegiatan hampir selalu terjadi manipulasi. Seperti berita yang tersebar dalam salah satu koran mingguan di Padang, bahwa dalam laporan pertangungjawaban mengenai transportasi terdapat tiket pesawat fiktif. Begitu pula terkait waktu, dalam laporan disebutkan lama perjalanan 14 hari namun yang terpakai hanya 3-4 hari (Isra, 2006; Redaksi, 2000).

Pada tanggal 30 November 2000, ditetapkan PP No. 110 Tahun 2000 tetang Kedudukan Keuangan Dewan Perwakilan Rakyat Daerah. ${ }^{4}$ Bagi sebagian besar Anggota DPRD, berlakunya PP (Peraturan Pemerintah) No. 110 Tahun 2000, dianggap bertentangan dengan undang-undang. DPRD Provinsi Sumatera Barat mengirim surat kepada Presiden Republik Indonesia dan Ketua Mahkamah Agung untuk melakukan uji materi (Judicial Review) terhadap PP tersebut pada tanggal 15 Januari 2001. Pada tanggal 2 Agustus 2001, permohonan uji materi terhadap PP tersebut yang dilakukan DPRD Sumatera Barat ditolak oleh Mahkamah Agung karena peraturan tersebut tidak bertentangan dengan UU No. 4 Tahun 1999 dan UU No. 22 Tahun 1999 serta sesuai dengan azas demokrasi (DPRD Sumatera Barat, 2004).

Dalam penyusunan RAPBD Sumatera Barat tahun 2002, di tingkat fraksi, M. Zen Gomo sudah menunjukkan penolakan terhadap usulan rancangan anggaran yang dinilainya tidak sesuai dengan PP No. 110 Tahun 2000 yang berlaku. Upaya penolakan tersebut, tidak membuahkan hasil

\footnotetext{
${ }^{3}$ Isu politik uang memang berkembang di tengah masyarakat pada saat pemilihan gubernur tahun 2002 ini. Kode yang dimaksud ialah setiap calon anggota DPRD yang menerima uang tersebut mencoblos surat suara dengan sudut atau posisi coblosan yang telah ditentukan, misal si $\mathrm{A}$, mencoblos huruf pertama nama calon gubernu, si B mencoblos huruf kedua, si C mencoblos gambar dan seterusnya. Namun isu mengenai politik uang tersebut memang tidak dapat dibuktikan secara hukum.

${ }^{4}$ Selanjutnya PP tersebut diundangkan dalam Lembaran Negara Republik Indonesia tahun 2000 No. 211 pada tanggal 30 November 2000.
} 
karena Zen kalah suara (Alfian, 2016; Efendi, 2016). Begitu juga pada saat rapat yang diadakan dalam Panitia Anggaran. Pada pertemuan yang ketiga tanggal 3 Desember 2001 dilakukan pembahasan tentang perlu atau tidaknya revisi anggaran yang sebelumnya berjumlah Rp12.000.000.000,00 setelah adanya masukan menjadi Rp13.790.541.800,00. Syahrial ${ }^{5}$ menjelaskan bahwa dalam menyusun anggaran belanja dewan DPRD harus berpedoman pada PP. No. 110 Tahun 2000 karena merupakan hukum positif. Jika PP tersebut dilanggar maka akan menimbulkan resiko. M. Zen Gomo juga memberikan tanggapan agar rencana draf anggaran tahun 2002 direvisi, karena terlalu tinggi, yang berakibat, DPRD akan dihujat oleh rakyat. Selain itu Marhaeni Azuar juga mengusulkan agar anggaran tersebut direvisi atau sama dengan tahun yang lalu. Ternyata tanggapan M. Zen Gomo dan Marhaeni Azuar serta penjelasan Syahrial sebagai pimpinan tidak respon oleh peserta rapat (Mahkamah Agung Republik Indonesia Pengadilan Militer Tinggi I Medan, 2004).

Selanjutnya DPRD Sumatera Barat mengeluarkan keputusan No. 16/SB/2001 tentang Penetapan Anggaran Belanja Dewan Perwakilan Rakyat Daerah Provinsi Sumatera Barat Tahun Anggaran 2002. Anggaran tersebut terdiri atas dua jenis belanja, yaitu belanja rutin dan belanja pembangunan DPRD. Belanja rutin DPRD sebesar Rp11.493.411.800,00; belanja sekretariat Rp6.823.347.000,00 dan belanja pembangunan dewan Rp1.264.450.000,00.

Pada bulan Januari, menjelang penetapan APBD Sumatera Barat tahun 2002, muncul protes dari berbagai kelompok masyarakat sipil baik, dalam tahap selanjutnya berkembang menjadi Forum Peduli Sumatera Barat (FPSB) $^{6}$ (Isra, 2006; Zed, 2016). "Bak gayung bersambut", dari internal DPRD, M. Zen Gomo melakukan upaya revisi, sementara dari luar FPSB juga sedang melakukan gerakan dengan tujuan yang sama. Kesamaan tujuan inilah yang membuat Zen diajak bekerja sama oleh FPSB untuk menuntut dewan melakukan revisi APBD Sumbar tahun 2002. Kerjasama antara Zen dan FPSB merupakan sebuah kekuatan yang saling menguatkan. Zen memperoleh dukungan yang kuat dari masyarakat sehingga ia tidak bergerak sendirian ditambah dengan FPSB diisi oleh orang-orang yang kuat, baik secara masa, strategi maupun keilmuannya. Begitu juga FPSB memiliki kekuatan dan dorongan yang semakin besar karena langsung didukung oleh orang dari dalam lembaga tersebut (Isra, 2016; Zed, 2016).

\footnotetext{
${ }^{5}$ Pimpinan Dewan, menjabat sebagai Wakil Ketua DPRD Sumatera Barat 19992004.

6 FPSB merupakan wadah/koordinator dari berbagai kalangan yang ingin berpartisipasi dan mendukung gerakan anti korupsi di Sumatera Barat (Zed, 2016).
} 
M. Zen Gomo dalam Gerakan Anti Korupsi pada Dekade I Reformasi...

Dalam diskusi-diskusi yang diadakan oleh FPSB, Zen sering diundang dan hadir. Pada saat itu, ia berperan untuk memberikan data-data yang ia miliki terkait masalah APBD tersebut. Selain itu ia juga memberikan informasi tentang situasi dan kondisi di dalam DPRD sendiri dalam menganggapi tuntutan yang oleh masyarakat (Danil, 2016; O. Rizwa, 2016; Ruzuar, 2016). Setelah melakukan diskusi dan kajian kritis berdasarkan pada informasi yang telah diperoleh dan diolah, FPSB membuat laporan yang disampaikan kepada Kepala Kejaksaan Tinggi Sumatera Barat. Dalam laporan tersebut FPSB melihat adanya penyimpangan-penyimpangan yang mengandung indikasi korupsi. Di antaranya ialah:

1) Pengalokasian dana premi asuransi Pimpinan dan Anggota DPRD sebesar Rp2.519.200,00 perorang setiap bulan, sehingga seluruhnya berjumlah Rp1.662.672.000,00. Pemberian premi asuransi bagi pimpinan dan anggota DPRD adalah sesuatu yang tidak dikenal dan tidak sesuai dengan Peraturan Pemerintah No. 110 Tahun 2000 tentang Kedudukan Keuangan DPRD.

2) Pengalokasian dana tunjangan kesejahteraan sebesar Rp1.320.000.000,00 untuk 55 orang anggota dewan. Pengalokasian dana tunjangan ini dimunculkan pula pada pos lain dalam bentu dana pemeliharaan kesehatan sebesar Rp367.014.000,00. Padahal yang dimaksud dengan tunjangan kesejahteraan dalam Pasal 10 PP No. 110 tidak lain adalah tunjangan kesehatan itu sendiri yang diberikan dalam bentuk jaminan asuransi kesehatan.

3) Pengalokasian dana tunjangan kehormatan sebesar Rp600.000.000,00 dengan rincian, untuk ketua DPRD selama satu tahun Rp13.200.000,00. Tiga orang wakil ketua selama satu tahun Rp36.000.000,00. Dan untuk 51 orang anggota dewan selama satu tahun sebesar Rp550.000.000,00.

4) Pengalokasian dana sewa rumah dinas wakil ketua dan sewa rumah dinas anggota serta Sektretariat DPRD sebesar Rp643.100.000,00 dengan rincian, untuk dua orang wakil ketua sebesar Rp29.500.000,00. Untuk anggota dan sekretaris dewan sebesar Rp613.600.000,00.

5) Pengalokasian biaya perjalanan dinas DPRD, terutama sekali biaya perjalanan dinas paket Studi Banding Luar Daerah Masa Sidang III sebesar Rp797.500.000,00 untuk 55 orang, dengan empat kali perjalanan selama satu tahun (Forum Peduli Sumatera Barat (FPSB), 2002).

Pada tanggal 6 April 2002, M. Zen Gomo "membuka kartu" atau kebohongan yang dilakukan dewan dalam kegiatan dengar pendapat di UNP (Redaksi, 2002a). Setelah tindakannya tersebut, tuntutan dari mahasiswa, masyarakat dan LSM yang tergabung dalam koordinasi FPSB 
semakin bergulir. Sementara di dalam DPRD tidak tampak keinginan untuk melakukan revisi anggaran. Maka pada tanggal 22 Mei 2002 ia memilih untuk melakukan mogok kerja dan mengancam mundur jika dewan tidak mau melakukan revisi anggaran. Pada saat mogok kerja tersebut ia mengajukan "Tuntutan Pembenahan Citra Kinerja Dewan" yang berisi antara lain:

1) Adanya indikasi pemakaian uang eksekutif oleh legislatif sebesar Rp929.000.000,00.

2) Adanya pemborosan yang bertentangan dengan PP No. 110 dan UU No. 31 Tahun 2000 (UU tentang Anti Korupsi) sekitar Rp6.000.000.000,00 (yang dituduhkan oleh kejaksaan sebesar Rp5.900.000.000,00).

3) Tidak adanya kode etik yang bisa mengatur tingkah laku para anggota dewan.

4) Tidak adanya tim ahli yang mengakibatkan fungsi kontrol terhadap eksekutif tidak berjalan sebagaimana mestinya karena keterbatasan SDM yang ada.

5) Pembahasan APBD harus transparan.

Sementara itu, pimpinan DPRD dan pimpinan fraksi langsung mengadakan pertemuan pasca mogok kerja yang dilakukan M. Zen Gomo (Redaksi, 2002b). Sehari setelah M. Zen Gomo melakukan mogok kerja, datang surat jawaban dari dewan yang bermaksud menolak tuntutannya. Maka pada tanggal 24 Mei 2002 ia mengajukan surat kepada Mendagri agar membatalkan APBD Sumatera Barat tahun 2002 (Gomo, n.d.-b). Pada hari yang sama, berdasarkan laporan yang telah disampaikan oleh Forum Peduli Sumatera Barat (FPSB), Kejati mengeluarkan surat No. B-66 N 3 Fd. 104 2002 agar dewan membatalkan APBD tahun 2002 yang bertentangan dengan UU No. 31 Tahun 1999 dan UU No. 20 Tahun 2000 (Gomo, n.d.b).

Tiga minggu setelah melakukan mogok kerja M. Zen Gomo memenuhi panggilan Kejati Sumbar untuk melakukan klarifikasi seputar mogok kerja yang ia lakukan. Di samping itu ia juga ditanya tentang dewan yang telah melakukan pembohongan publik, terutama dalam penyusunan APBD Sumbar tahun 2002. Sehari setelah itu, Kejati mengatakan jika informasi yang disampaikan oleh M. Zen Gomo benar dan memenuhi ketentuan tindak pidana korupsi maka Kejati akan mengusut segera kasus tersebut. Data-data yang dibutuhkan untuk mengusut kasus tersebut lengkap, sehingga turunlah izin dari Mendagri tanggal 7 November 2002 
untuk memeriksa Anggota DPRD Sumatera Barat dan M. Zen Gomo ditetapkan sebagai saksi (Gomo, n.d.-b).

Berkat tindakan yang dilakukan oleh M. Zen Gomo dan upaya-upaya yang dilakukan oleh FPSB, akhirnya 43 anggota DPRD Provinsi Sumatera Barat periode 1999-2004 dinyatakan bersalah. ${ }^{7}$ Putusan terhadap mereka telah ditetapkan setelah dikuatkan Mahkamah Agung. Keberhasilan ini menjadi inspirasi bagi daerah lain untuk mengungkap kasus yang sama (Widjojanto, 2006).

Setelah melakukan protes dan mogok kerja yang diikuti dengan gerakan untuk mengungkap kasus tersebut, M. Zen Gomo memutuskan untuk mundur dari kursi DPRD Sumatera Barat. Pada tanggal 17 Februari 2003 ia mengajukan surat pengunduran diri. Ketika mengajukan surat pengunduran diri tersebut, Zen masih dibujuk untuk bertahan di DPRD. Bujukan itu datang dari beberapa temannya di DPRD, partai dan lingkungan sekitarnya, namun karena itu sudah menjadi keputusannya, Zen tetap pada pendirian dengan memiih mundur dari DPRD Sumatera Barat. Pada tanggal 16 Juni 2003, keluar Surat Keputusan pemberhentian dengan hormat dari Menteri Dalam Negeri (Gomo, n.d.-b).

Setelah mundur dari DPRD Sumatera Barat, M. Zen Gomo masih aktif terlibat di partai. Pada saat di partai, ia merasa mendapat sambutan yang kurang baik, walaupun dukungan secara politis tetap diberikan. Perlakuan yang sangat kentara baginya ialah pada saat Hari Ulang Tahun PAN yang ke IV, ia ditunjuk sebagai ketua serta semua biaya dibebankan kepadanya dan sama sekali tidak ditanggung oleh Dewan Pimpinan Wilayah. Kemudian saat kampanye Pemilu Legislatif tahun 2004 dengan berbagai alasan ia tidak diikutsertakan (Gomo, n.d.-b).

Akhir tahun 2005, di dalam kepengurusan PAN Sumbar sedang berlangsung proses pemilihan Ketua Dewan Pengurus Wilayah (DPW). Pada waktu itu, M. Zen Gomo menjadi salah seorang calon ketua. Sebelum nama-nama calon tersebut masuk dalam Muswil, panitia melakukan proses penyaringan terlebih dahulu. Setelah dilakukan proses penyaringan, M. Zen Gomo berada di urutan keempat setelah Asli Chaidir (121 suara), Yosmeri

${ }^{7}$ Dalam perkembangan selajutnya, para anggota DPRD Sumbar yang telah divonis tersebut mengajukan banding ke Pengadilan Tinggi Sumatera Barat, tetapi putusan banding itu lebih berat dari putusan PN Padang, yaitu 4-5 tahun penjara dan denda 200250 juta yang dibacakan pada tanggal 24 Desember 2004. Dan pada 2 Agustus 2005 kasasi yang diajukan anggota DPRD Sumbar ditolak oleh MA. Namun dalam tahap selanjutnya, MA menerima kasasi dan memberikan vonis bebas kepada 10 orang anggota DPRD pada tanggal 10 oktober 2007, dan pada tanggal 25 Februari 2008, semua anggota DPRD Sumbar yang terkait dengan kasus tersebut juga memperoleh vonis bebas dari Mahkamah Agung setelah pengajuan Peninjauan Kembali (PK)-nya diterima. 
Yusuf (42 Suara), Amri Darwis (30 suara) dan Zen (13 Suara). Jika dipersentasekan ia hanya memperoleh $5,5 \%$ dari total suara keseluruhan.

Hasil penyaringan tersebut dikirim ke DPP PAN di Jakarta untuk penentuan nama-nama yang berhak untuk dipilih saat Muswil. Pada saat Muswil, M. Zen Gomo tidak masuk ke dalam daftar calon ketua. Namanama yang masuk sebagai calon ketua dalam Muswil tersebut ialah Asli Chaidir, Yosmeri Yusuf, dan Amri Darwis. Mereka merupakan tiga orang bakal calon yang memperoleh suara terbanyak. Kurangnya dukungan terhadap M. Zen Gomo, menunjukkan bahwa tindakannya tersebut tidak begitu populer di partai (Redaksi, 2002c). ${ }^{8}$ Selain itu, kuatnya money politik dalam pemilihan tersebut yang dilakukan oleh salah seorang kandidat juga menjadi salah satu faktor M. Zen Gomo kalah (Inoki, 2016; D. Rizwa, 2016; Taslim, 2016).

Musywil II tersebut dimenangkan oleh Asli Chaidir, sehingga ia diangkat menjadi ketua Dewan Pengurus Wilayah (DPW) PAN Sumatera Barat untuk periode 2005-2010. Pada masa ini, banyak kader PAN yang memutuskan untuk keluar dari PAN dan mencari kendaraan politik lain (Lanin, 2016; Taslim, 2016). Tindakan serupa juga dilakukan oleh M. Zen Gomo, namun berbeda dari rekan-rekannya sesama kader PAN, ia lebih memilih untuk keluar dari partai dan meninggalkan kehidupan politik. Keluarnya M. Zen Gomo memang tidak ada pernyataan resmi seperti yang diajukan pada saat mundur dari DPRD Sumatera Barat. Ia hanya memilih untuk tidak mengikuti dan menghadiri semua kegiatan yang dibuat oleh partai. Inilah yang menjadi penanda bahwa M. Zen Gomo telah mengakhiri kariernya dalam dunia politik di Sumatera Barat.

\section{KESIMPULAN}

Berdasarkan paparan diatas, dapat dikatakan bahwa keberadaan M. Zen Gomo memiliki arti penting dalam gerakan anti-korupsi era reformasi di Sumatera Barat. Ia merupakan icon dalam membangkitkan semangat serta membuka mata masyarakat. Selain itu ia juga merupakan salah seorang sumber informasi dalam gerakan anti korupsi tersebut. Media lokal dan nasional pada waktu itu cukup memberi perhatian kepada M. Zen Gomo sebagai sesuatu yang penting dalam gerakan anti-korupsi, walaupun dalam sudut pandang dan kepentingan berbeda ada juga yang menyanksikan

${ }^{8}$ Dalam pandangan masyarakat umum, tindakan yang dilakukan oleh M. Zen Gomo memang mendapat respon positif dari masyarakat. namun dari sudut pandang sesama anggota dewan dan politik. tindakan yang dilakukan M. Zen Gomo dianggap sebagai pengkhianatan terhadap lembaga dan partai. 
M. Zen Gomo dalam Gerakan Anti Korupsi pada Dekade I Reformasi...

peranannya. Setidaknya tindakan M. Zen Gomo tersebut merupakan titik kecil dalam sejarah, menjadi bagian yang tak terpisahkan dari gerakan anti korupsi pada dekade I Reformasi di Sumatera Barat.

\section{REFERENSI}

Alfian. (2016). W awancara. Bukittinggi.

Asnan, G. (2006). Pemerintahan Sumatera Barat dari VOC bingga Reformasi. Yogyakarta: Citra Pustaka.

Danil, E. (2016). Wawancara. Padang.

Denzim, N. K., \& Lincoln, Y. S. (1994). Handbooks of Qualitative Research. London: Sage.

DPRD Sumatera Barat. (2004). Memori DPRD Sumatera Barat tahun 19992004. Padang: DPRD Sumatera Barat.

DPW PAN Sumatera Barat. (n.d.). Struktur Dewan Pimpinan Wilayah Partai Amanat Nasional (DPW PAN) Sumatera Barat periode 1998-1999. Padang.

Efendi, M. (2016). Wawancara. Padang.

Forum Peduli Sumatera Barat (FPSB). (2002). Forum Peduli Sumatera Barat kepada Kepala Kejaksaan Tinggi Sumatera Barat tentang Informasi dan Laporan Tindak Pidana Korupsi. Padang.

Gomo, M. Z. (n.d.-a). CV M. Zen Gomo. Padang.

Gomo, M. Z. (n.d.-b). Hari-hari Kelabu di DPRD Provinsi Sumatera Barat. Padang.

Gottschalk, L. (1975). Mengerti Sejarah. (N. Notosusanto, Ed.). Jakarta: Yayasan Penerbit Universitas Indonesia.

Inoki. (2016). Wawancara. Padang.

International IDEA. (2000). Penilaian Demokratisasi di Indonesia. Stockholm: International IDEA.

Isra, S. (2006). Wakil Rakyat Menjarah Uang Rakyat. In D. Trisasongko, S. A. Schuette, \& V. S. Wardhana (Eds.), Melawan Korupsi dari Aceh sampai Papua: 10 Kisah Pemberantasan Korupsi di Indonesia (pp. 132-175). Jakarta: Kemitraan Partnership.

Isra, S. (2010). Membangun Demokrasi Membongkar Korupsi: Sebuah Kumpulan Wawancara. Jakarta: Raja Grafindo Persada.

Isra, S. (2016). Wawancara. Padang.

Lanin, D. (2016). Wawancara. Padang.

Mahkamah Agung Republik Indonesia Pengadilan Militer Tinggi I Medan. Direktori Putusan Mahkamah Agung Republik Indonesia Pengadilan Militer Tinggi I Medan, Pub. L. No. PUT/04-K/PMTI/AD/VI/2004 (2004). Indonesia: Putusan Mahkamah Agung. 
Menteri Dalam Negeri. Surat Keputusan Menteri Dalam Negeri Republik Indonesia tentang Peresmian Pengangkatan dan Peresmian Pemberhentian Anggota Dewan Perwakilan Daerah Propinsi Sumatera Barat tahun 1999, Pub. L. No. 161.23-916 (1999). Indonesia: Surat Keputusan.

Redaksi. (2000). DPRD Sumbar Hamburkan 200 Juta dengan Melakukan Penyimpangan Terselubung. Canang.

Redaksi. (2002a, April 8). Anggota Dewan M. Zen Gomo Buka Kartu, DPRD Berhentilah Berbohong. Singgalang.

Redaksi. (2002b, May 24). Anggota DPRD Sumbar Mogok. Mimbar Minang. Redaksi. (2002c, June 22). Syahrial dan Masyfar Setuju Revisi APBD, Gomo: Terima Kasih Dicap Penghianat. Padang Ekspres.

Rizwa, D. (2016). Wawancara. Padang.

Rizwa, O. (2016). Wawancara. Padang.

Ruzuar, R. (2016). Wawancara. Padang.

Taslim. (2016). Wawancara. Jakarta.

Widjojanto, B. (2006). Upaya Membangun Gerakan Antikorupsi. In D. Trisasongko, S. A. Schuette, \& V. S. Wardhana (Eds.), Melawan Korupsi dari Aceh sampai Papua: 10 Kisah Pemberantasan Korupsi di Indonesia (pp. vii-xix). Jakarta: Kemitraan Partnership.

Zed, M. (2016). Wawancara. Padang. 